\title{
Cost-effectiveness of breast, lung, colon, prostate and cervical cancer outcomes in Brazil: a worldwide comparison
}

\author{
Rodrigo Pellegrini ${ }^{1}$, Tomás Reinert ${ }^{2,3}$ and Carlos Henrique Barrios ${ }^{2,3}$ \\ ${ }_{1}^{1}$ Pontifícia Universidade Católica do Rio Grande do Sul (PUCRS), School of Medicine, Av Ipiranga, 6681, Partenon, Porto Alegre, RS, 90619-900, Brazil \\ ${ }^{2}$ Latin American Cooperative Oncology Group (LACOG), Av Ipiranga, n 6681, Prédio 99ª , Sala 806, CEP 90619-900, Porto Alegre, RS, Brazil \\ ${ }^{3}$ Oncoclínicas, Av Praia de Belas, 1212, Sala 1606, Menino Deus, Porto Alegre, RS, 90110-000, Brazil
}

\begin{abstract}
Introduction: Cancer is the second leading cause of death in the world, and it is expected to be the main cause by the year 2030. Current trends of higher incidence and the introduction of new treatments lead to the challenge of treating more people with increasing costs per capita. In Brazil, current and future challenges are even more significant because of the limited resources destined for healthcare.
\end{abstract}

Methods: We propose a methodology to compare cost-effectiveness performance with a regression of cancer lethality against the resources available for different nations, using the gross domestic product and the mortality-to-incidence ratio. Our objective is to evaluate and compare outcomes observed in Brazil.

Results: According to our methodology, Brazil is performing well in breast and prostate cancer (observed lethality $9 \%$ and $15 \%$ lower than expected, respectively). It performs close to expected in colon ( $0.8 \%$ higher) and cervix ( $2 \%$ higher). However, lung cancer had a higher lethality than expected ( $6.5 \%$ higher). We also found that breast, prostate and cervical cancers are the primary sites more related to income. Lung cancer had the weakest relationship with resources.

Conclusion: Brazil has different cost-effectiveness results in the management of cancer depending on the primary site. Also, national income has a significant and heterogeneous effect on the lethality of different tumour types. This economic analysis is important for low- to middle-income countries seeking to evaluate cancer outcomes in limited-resource settings.

Keywords: cancer, efficiency, delivery of health care, incidence, mortality

\section{Introduction}

Cancer is one of the leading causes of death both for high-income countries (HIC) and low- to middle-income countries (LMIC). The estimated incidence for 2018 was 18 million cases with an associated mortality of 9.5 million deaths [1]. With the progressive growth and ageing of the population in association with an increasing prevalence of the main risk factors for cancer, this trend is expected to continue.
Correspondence to: Carlos Henrique Barrios Email: barrios@tummi.org

ecancer 2021, 15:1243

https://doi.org/10.3332/ecancer.2021.1243

Published: 07/06/2021

Received: 18/01/2021

Publication costs for this article were supported by ecancer (UK Charity number 1176307).

Copyright: $($ c the authors; licensee ecancermedicalscience. This is an Open Access article distributed under the terms of the Creative Commons Attribution License (http:// creativecommons.org/licenses/by/3.0), which permits unrestricted use, distribution, and reproduction in any medium, provided the original work is properly cited. 
It should be recognised that there are significant disparities across different countries. In the USA, the death rate for cancer was 215 per 100,000 in 1991, falling significantly to 159 per 100,000 in 2015. The American Cancer Society credits these impressive results to the reduction of smoking, the implementation of screening and early diagnosis programmes and the development of newer and better treatment modalities [2, 3]. Although having a lower incidence of cancer, Latin America has a more significant cancer mortality burden than the USA or main European countries. All cancer mortality-to-incidence ratio (MIR) is 0.59 in Latin America, while it is much lower in the USA (0.35) and the European Union (0.43) [3]. Multiple factors have been proposed to explain these worse outcomes. Among them, poorly organised and fragmented health care systems and limited resources destined for cancer treatment are commonly cited [3].

At the same time, there are evident differences related to access to new treatments. The high cost of new drugs represents a significant barrier compromising availability in resource-limited scenarios. In 2014, the median cost of any new oral anticancer agent $(\$ 135,000$ a year) was six times greater than in the early 2000s [4]. While access is a universal problem, in Brazil, an upper-middle-income country, but with an income per capita close to one-sixth the one in the USA and one-fourth of the one in the EU, this problem clearly generates much more concern (see the Appendix for LMIC and HIC current definition) [5, 6].

In a setting of scarce resources, LMIC need to develop public health policies with established cost-effectiveness. To achieve that, it is also important to measure each country's performance in the management of cancer patients considering its available resources.

\section{Methods}

Our objective with this ecologic study is to measure the outcomes of cancer management in Brazil, given its level of income, and compare it with other nation's outcomes.

\section{Variables}

As a measure of outcome, the MIR is a well-known proxy for the lethality in cancer patients [3, 7-9]. It is calculated by dividing the number of deaths by the incidence of a specific cancer type during a certain period. This ratio gives us the percentage of patients who will die from cancer (lethality), while the remaining share represents all the patients cured with treatment (survival ratio $=1-$ MIR). It must be noted that both early diagnosis and better treatment have an impact on this ratio, reducing the number of deaths in relation to the total number of cases.

To estimate each country's income restriction, we used the gross domestic product per capita (GDPpc). In economics, the GDPpc represents the whole production of a country divided by the number of citizens. Therefore, it has the same value as the median income per person (with taxes). Important to note in our study, because of the different characteristics of health care systems, the government expenditure per person is also considered in this calculation, resulting in the total amount of private and public expenditures. Therefore, with a regression of the MIR (as outcome) by the GDPpc (resources restraint), we can simulate a regression of cancer lethality by resource availability, estimating each country's cost-effectiveness in dealing with cancer [10].

\section{Data}

In order to create the regression, we used data from two different sources. The cancer incidence and mortality data for 2018 for each country were acquired from the International Agency for Research on Cancer, an institution of the World Health Organization (WHO) [11]. We used the age-standardised incidence rate and age-standardised mortality rate rather than the crude rates to diminish the impact of the populations' heterogeneity. We selected data with an estimated error limited to $15 \%$ (already calculated by the WHO) to give more credibility to our analysis.

The GDPpc was acquired from the World Bank database, also for the year of 2018. We had two possible alternatives for GDP selection. GDPpc with current dollars or GDPpc with purchasing power parity. As different countries in the world have different inflation and exchange rates, the first option seemed more reliable to denote their citizens' wealth.

The selected cancer sites are those responsible for most cancer deaths in women (breast, lung, colon and cervix) and men (lung, prostate and colon) in Brazil [12]. 


\section{Model}

To address the comparison among different countries, we propose a regression of the MIR (as a measure of performance) of different countries against their GDPpc (a measure of resource restraint).

The regression was performed with an ordinary least squares (OLS) methodology, resulting in an equation reflecting the impact of GDPpc in the MIR for each primary site. Because of the exponential distribution of GDPpc across the world, we transformed the data to the logarithmic form.

This model generates three variables of interest: (i) Residues; (ii) Elasticities and (iii) R-squared (see Table 1 for description).

\section{Primary endpoint}

The residues for Brazil are the primary endpoint of this article. They represent, for each primary tumour, how each country is performing in the management of that cancer. If the residue is positive, it means the lethality is higher than what the regression indicates it should be, given its GDPpc (expected value).

\section{Secondary endpoints}

The elasticities and R-squared $\left(R^{2}\right)$ values will also be analysed. Each primary site generated one elasticity and one $R^{2}$. The elasticity represents how much the lethality of a tumour decreases when income doubles. The $\mathrm{R}^{2}$ value represents how much of the variation of a tumour's lethality between countries can be explained by their income variation.

\section{Results}

\section{Data}

Cancer incidence and mortality data from GLOBOCAN have 186 measurements. However, for each cancer site, we excluded countries with an estimated error of $15 \%$ or more. In general, most of the excluded data came from low-income countries. After this first screening, we

Table 1. Definitions and applicability of statistic and epidemiologic terms used in this article.

\begin{tabular}{|l|l|l|}
\hline \multicolumn{1}{|c|}{ Indicator } & \multicolumn{1}{|c|}{ Definition } & \multicolumn{1}{c|}{ Applicability for this article } \\
\hline MIR & Mortality of a disease divided by its incidence. & $\begin{array}{l}\text { It is a proxy for Lethality. } \\
\text { Example: MIR of 0.2 = Lethality of 20\% }\end{array}$ \\
\hline GDPpc & $\begin{array}{l}\text { Total production of one country divided by its population. It } \\
\text { has the same value of income per capita. }\end{array}$ & It is a proxy for the Resources Available. \\
\hline Residues & $\begin{array}{l}\text { Differences between the estimated values by the equations } \\
\text { and the real values. } \\
\text { In the graphic, it is the measure of the distance of a single } \\
\text { point to the regression line. }\end{array}$ & $\begin{array}{l}\text { Measures the Cost-Effectiveness of the management of can- } \\
\text { cer by one country. } \\
\text { A positive value means that the Lethality of a cancer site in one } \\
\text { country is higher than expected, given its income per capita. }\end{array}$ \\
\hline Elasticity & $\begin{array}{l}\text { Variable's sensitivity to the change in another variable. } \\
\text { In the graphic, it is the inclination of the regression line. }\end{array}$ & $\begin{array}{l}\text { Measures the decrease in the Lethality of each cancer when } \\
\text { the Income increases 100\%. }\end{array}$ \\
\hline R-squared & $\begin{array}{l}\text { Measure of how the variation of one variable can be explained } \\
\text { by another variable's variation. } \\
\text { In the graphic, it is the measure of the distance of all the points } \\
\text { from the regression line. }\end{array}$ & $\begin{array}{l}\text { Measures how much of the difference in the Lethality of one } \\
\text { primary cancer between countries can be explained by the } \\
\text { variation of Income. }\end{array}$ \\
\hline
\end{tabular}


matched the MIR (dividing each country's cancer mortality rate by its incidence) with the GDPpc from each country (some of them were not available for the year 2017, e.g. Venezuela). The Brazilian data had estimated errors lower than $15 \%$ for all cancer sites. Data were available from 76 countries for breast cancer, 82 for lung, 68 for colon, 68 for prostate and 56 for cervix.

\section{Regressions}

The regressions resulted in the graphics shown in Figure 1a-e (their equations are presented in the Appendix).

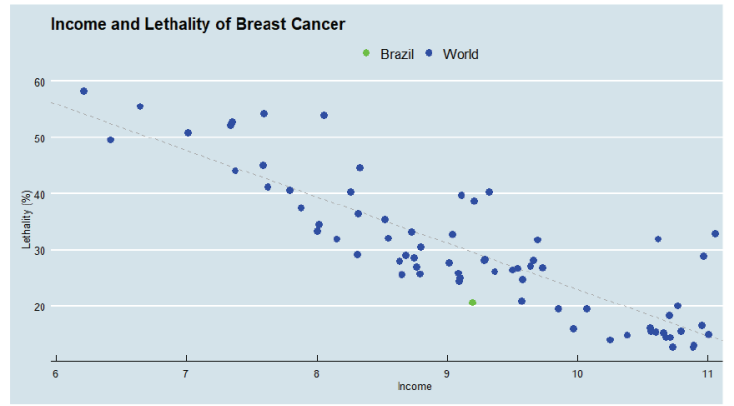

(a)

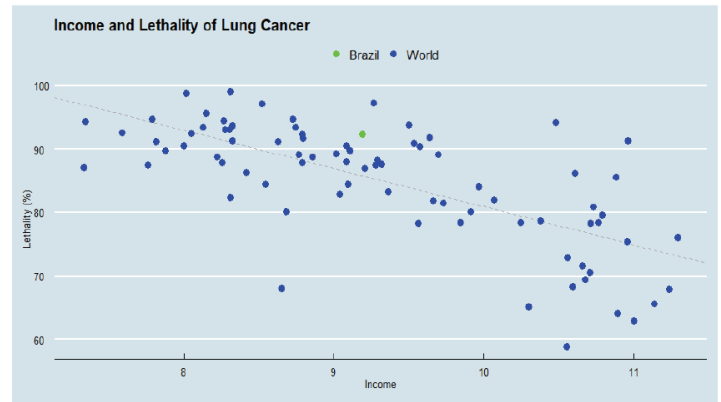

(c)

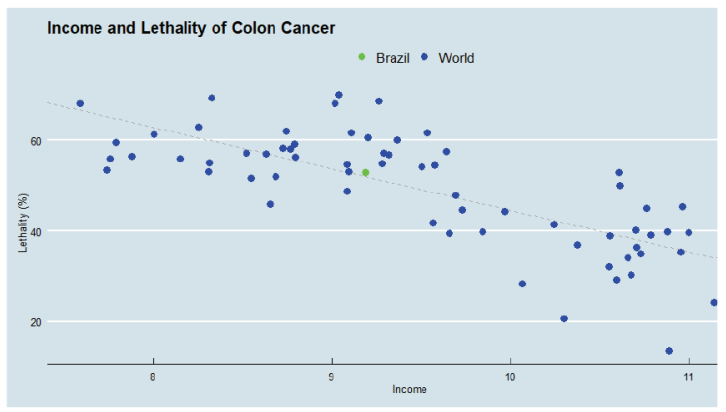

(b)

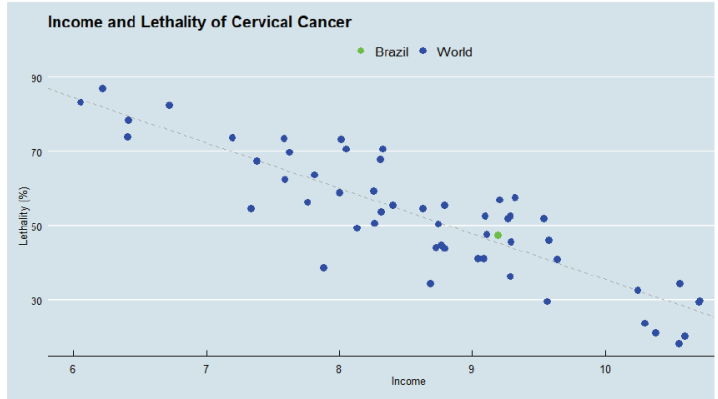

(d)

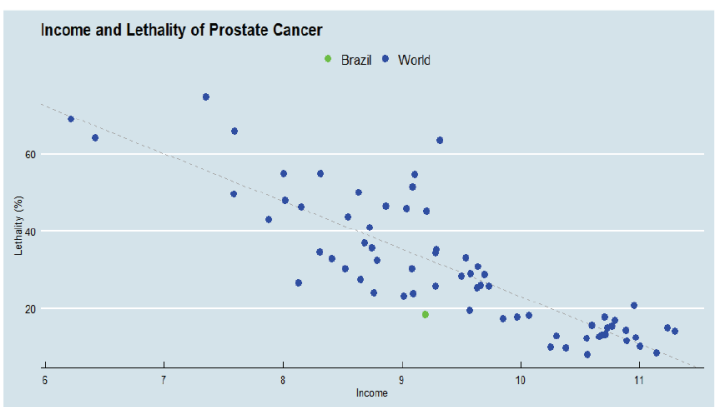

(e)

Figure 1. (a-e): Graphics for each cancer primary sites with data on the lethality (MIR) and income (GDPpc). Each point indicates one single country, and Brazil is indicated in green. When the green point (Brazil) is below the regression line in the graphic (such as for breast and prostate cancer), it indicates that the lethality of this primary site in Brazil is lower than it is in countries with similar income per capita. However, when the green point is above the regression line in the graphic (such as for lung cancer), the Brazilian lethality is higher than for countries with similar income per capita. Finally, when the green point is on the regression line (such as for colon and cervical cancer), results for Brazil are equal to the mean of similar income countries. 


\section{Brazil's outcomes}

The real lethality and the predicted lethality for each primary cancer site for Brazil are represented in Table 2, as well as their difference. The lethality of breast and prostate cancer in Brazil is lower than expected (by an absolute of $9 \%$ and $15 \%$, respectively). On the other hand, the lethality of lung cancer is higher than expected (6.5\%). Colon (0.8\%) and cervical cancer (1.9\%) had results close to the expected (Table 2 ).

\section{Elasticities}

The regressions' elasticities (the proportion of decrease in MIR with the increase of GDPpc) indicate that income has more impact on the lethality of prostate and cervical cancer. An increase of $100 \%$ of a country's income is expected to decrease the lethality of these primary sites by $8.5 \%$. For lung cancer, the impact is the lowest (4.1\%). Breast and colon cancer had intermediate values (5.7\% and $6.3 \%$, respectively).

\section{R-squared}

The $\mathrm{R}^{2}$ values (the percentage of the difference in MIR across countries that their difference in GDPpc can explain) indicate that breast, lung and cervical cancer are the tumour sites with the lethality variation best explained by the variation on available resources (75\%, $71 \%$ and 78\%) (Table 3). On the other hand, the variation of lung cancer lethality is explained only $47 \%$ by the variation in income across the countries. Colon cancer had an intermediate result (57\%).

\section{Discussion}

We achieved our objective of evaluating the outcomes of common cancer subtypes in Brazil in relation to its available resources, and we observed that breast and prostate cancer results indicate a good cost-effectiveness performance. Conversely, lung cancer had a higherthan-expected lethality given the Brazilian GDPpc. Also, we obtained elasticities and R-squared results for each cancer site, representing a measure of the worldwide impact of income, suggesting that breast, prostate and cervical cancer lethality were all well explained by the model (as indicated by their high R-squared) and are strongly impacted by the increase in the availability of resources (as indicated by their high elasticities). However, lung cancer had both the lowest elasticity and R-squared [13, 14].

This analysis is important in the current context of increasing cancer incidence as well as cancer treatment costs. This scrutiny has a different impact across nations, mainly due to the worldwide variation on wealth, which is an already known cause for the difference in outcomes between HICs and LMICs [15-17].

Table 2. Results of the regressions for each primary site showing the Brazilian real lethality (calculated from the MIR), the predicted lethality by the model and the differences between these results (which are called residues). Positive residues indicate that the lethality of cancer is higher than it should be, based on its income per capita.

\begin{tabular}{|l|c|c|c|}
\hline \multicolumn{1}{|c|}{ Site } & Brazilian real lethality & Brazilian predicted lethality & Difference (residue) \\
\hline Breast & $20 \%$ & $29 \%$ & $-9 \%$ \\
\hline Lung & $92 \%$ & $85 \%$ & $6 \%$ \\
\hline Colon & $52 \%$ & $51 \%$ & $1 \%$ \\
\hline Prostate & $18 \%$ & $33 \%$ & $-15 \%$ \\
\hline Cervical & $47 \%$ & $45 \%$ & $2 \%$ \\
\hline
\end{tabular}


Table 3. Results of elasticity and R-squared values for the regressions of each primary site.

\begin{tabular}{|l|c|c|}
\hline \multicolumn{1}{|c|}{ Site } & Elasticity & R-squared \\
\hline Breast & $5.7 \%$ & $75 \%$ \\
\hline Lung & $4.1 \%$ & $47 \%$ \\
\hline Colon & $6.3 \%$ & $57 \%$ \\
\hline Prostate & $8.5 \%$ & $71 \%$ \\
\hline Cervix & $8.4 \%$ & $78 \%$ \\
\hline
\end{tabular}

In this ecologic study, we used available data from the World Bank and the WHO to evaluate the relation of GDPpc (as a measure of available resources) and the MIR (as a measure of cancer outcomes) with a particular focus on the results for Brazil. With this regression, we were able to analyse if the lethality of breast, lung, colon, prostate and cervix cancer in Brazil was compatible with its level of income. Also, the two other results generated by the model (elasticities and $\mathrm{R}^{2}$ ) are measures of the relationship between GDPpc and MIR data for each primary site.

Our analysis showed that the lethality of breast cancer in Brazil is $20 \%$, while the country's GDPpc would suggest a lethality of $29 \%$. Its $\mathrm{R}^{2}$ demonstrates that income is a good predictor for breast cancer lethality, with 75\% of MIR variation being explained by GDPpc. This data is compatible with the results of the literature on this subject [16]. We list two possible factors that could explain the better results of breast cancer patients in Brazil: the national screening programme and the adoption of high-quality treatments by the public health care system. Regarding screening, the Brazilian Ministry of Health indicates in its national guideline that all women 50-69 years should have periodic mammography with an interval of 2 years [18]. When we look at the staging at diagnosis data, the AMAZONA project indicates that $68 \%$ of breast cancer cases present in stages I and II in Brazil [19]. Even though these numbers could be improved and are lower than those observed in the USA, when we compare them to the data of a Lancet meta-analysis for African regions (West Africa $=23.35 \%$; East Africa $=22.69 \%$; Southern Africa (Black) = 22.32\%; Southern Africa (White) $=47.7 \%$ ), we consider them a reasonable outcome [20]. As for the quality of the Brazilian health care system's treatment of breast cancer, since 2012, trastuzumab is offered at no cost to patients in the adjuvant setting. In metastatic disease, Trastuzumab approval for Sistema Único de Saúde (SUS, the Brazilian public health care system) patients came only in 2017 [21]. The system is organised with central purchases: the government makes big purchases each year (given the new-cases estimate), and then distributes the drug according to demand. This well-organised system may be considered an accomplishment, considering that it is a challenge to offer high-priced treatments even in nations with higher income per capita [22].

The observed lethality of lung cancer was higher than expected considering the national income in Brazil by $6.5 \%$. However, data suggest that the relationship between lung cancer outcomes and wealth is weaker than for other primary sites. GDPpc can explain only $47 \%$ of the MIR variation, and a decrease of $4 \%$ in MIR is expected with a one-fold increase in GDPpc. This conclusion is in accordance with the results found in a meta-analysis published by Finke et al [14] on the relationship between lung cancer survival and socioeconomic differences. This higher lethality of lung cancer in Brazil requires careful analysis. Published data shows that lung cancer has a weaker association between income and survival. Despite good treatment options for some patients, survival is still relatively low. In virtue of the aggressiveness of this disease, it seems that currently available treatments do not have a significant impact on survival ratios (the 5-years survival rate in the USA is no more than 20\%). Additionally, even in HIC, the disease is usually diagnosed in the advanced stage setting. SEER data shows that almost $80 \%$ of lung cancers are diagnosed already with locoregional or distant disease. The recent availability of immunotherapies that have revolutionised the management of advanced lung cancer and that may significantly extend the survival of some patients may play an important role in future analyses as the associated high costs will compromise access in LMIC.

In prostate cancer, it is well documented that incidence is higher and mortality is lower in HICs in comparison with LMICs [15]. Our findings are in accordance with this statement, as $71 \%$ of the variation on MIR could be explained by GDPpc, and a decrease of more than $8 \%$ is expected when GDPpc doubles. In Brazil, the observed lethality was found to be $15 \%$ lower than the predicted model (33\% versus $18 \%$ ). In prostate cancer, overdiagnosis and overtreatment are factors to consider in view of the indolent nature of the disease. The good performance 
in our model may be explained by confounding factors such as higher rates of incidence. Of note, the Brazilian incidence of prostate cancer (82 per 100,000) is higher than in Argentina (53), Chile (72), Colombia (52) and Peru (46). Furthermore, 70\% of prostate cancers in Brazil are diagnosed as localised disease [11].

For cervical cancer, both incidence and mortality are lower in HICs than in LMICs. Considering that defined prevention strategies are widely available for this cancer, we should note there are significant differences in implementation between countries [17]. Our results found that GDPpc explains $78 \%$ of MIR data (the highest of all primary sites) with an elasticity of $8.4 \%$. In our analysis, the observed lethality of cervical cancer in Brazil is close to the result predicted by the model (45\% versus $47 \%$ ).

The epidemiology of colon cancer is facing a transition. Developed countries are seeing a reduction in both incidence and mortality rates, while developing countries deal with an increase in both incidence and mortality rates [23]. Our results demonstrate intermediate values of elasticity (6.3\%) and $\mathrm{R}^{2}$ (57\%) - not as high as for breast, prostate and cervix, and not as low as lung cancer. The Brazilian result indicates that the observed lethality is in accordance with the value predicted by the model ( $52 \%$ and $51 \%)$.

This study can be a helpful tool for policymakers to decide how to best allocate resources in a scenario of limited availability. Results of elasticity and R-squared indicate that some tumours (with higher values) may be more sensible and impacted by the increase in resource application. We can conclude that investing in early diagnosis and the treatment of such primary sites may be more cost-effective than in others. For LMIC, this analysis is crucial given the current situation of increasing cancer incidence and costs. In our analysis, as previously demonstrated, breast, prostate and cervical cancer have stronger relationships with income than lung cancer [15-17].

Our analysis has limitations. There is no absolute indicator for the management of cancer. We used the MIR as the outcome proxy because it represents the lethality of cancer. It must be noted that not only the treatment efficacy impacts this indicator but also early diagnosis since more advanced cancer has a worse prognosis. This is the reason why we used the term outcomes of the management of cancer and not treatment. In addition, if we used the mortality rate isolated as our indicator, we would not be able to compare countries with different incidence rates. With MIR, we have not this problem.

We conducted this study using only income per capita as our main regressor and chose not to use factors such as the Human Development Index (HDI), the Gini index, the education level, the expenditure on health and the number of doctors. The reason was to focus on a simpler model with the most reliable data since the GDP is a better indicator with a more uniform calculation method than expenditure on health, mainly due to the different types of health care systems across the world. Since we used the GDP as the regressor, both public and private wealth are represented as resources available. In accordance with previous studies, we believe that GDP can be considered as one of the main factors to explain differences between countries' cancer outcomes [16].

Equally important, the quality of the basic data needs careful consideration. To address this factor, we used published data from the WHO and the World Bank.

\section{Conclusion}

Careful analysis of real-world data allows for better assessment of some observed disparities in cancer outcomes between HIC and LMIC. Strategic planning and resource allocation, particularly in limited resource scenarios, could benefit from this exercise. This analysis should be considered dynamic and subject to change as new therapeutic modalities become available, changing treatment outcomes for given tumour types. According to our results, while breast and prostate cancers have a good cost-effective performance in Brazil, in contrast, lung cancer has a worse than expected outcome, although it had the weaker relation of income and lethality of all tumours. In addition, investing in the diagnosis and treatment of certain specific tumours generates a higher impact on outcomes.

\section{Funding}

No funding was received. 


\section{Conflicts of interest}

Rodrigo Pellegrini:

- None

Tomás Reinert:

- Speaker honoraria: Novartis, AstraZeneca, Pfizer, Libbs, Lilly, Pierre Fabre

- Consulting or advisory role: AstraZeneca, Lilly, Novartis

- Research funding: AstraZeneca

Carlos Henrique Barrios:

- Stock and other ownership interests: Biomarker, MedSIR, Tummi

- Speaker honoraria: Novartis, Roche/Genentech, Pfizer, GlaxoSmithKline, Sanofi, Boehringer Ingelheim, Eisai

- Consulting or advisory role: Boehringer Ingelheim, Roche/Genentech, Novartis, GlaxoSmithKline, Eisai, Pfizer, AstraZeneca, Libbs, MSD Oncology, United Medical

- Research funding: Pfizer, Novartis, Amgen, AstraZeneca, Boehringer Ingelheim, GlaxoSmithKline, Roche/Genentech, Lilly, Sanofi, Taiho Pharmaceutical, Mylan, Merrimack, Merck, AbbVie, Astellas Pharma, Biomarin, Bristol-Myers Squibb, Daiichi Sankyo, Abraxis BioScience, AB Science, Asana Biosciences, Medivation, Exelixis, ImClone Systems, LEO Pharma, Millennium, Janssen, Atlantis Clinica, INC Research, Halozyme, Covance, Celgene, inVentiv Health

- Travel, accommodations, expenses: Roche/Genentech, Novartis, Pfizer, BMS Brazil, AstraZeneca, MSD Oncology

\section{References}

1. Bray F, Ferlay J, and Soerjomataram I, et al (2018) Global cancer statistics 2018: GLOBOCAN estimates of incidence and mortality worldwide for 36 cancers in 185 countries CA Cancer J Clin 68(6) 394-424 https://doi.org/10.3322/caac.21492 PMID: 30207593

2. American Cancer Society Institution (2018) Cancer Facts \& Figures (New York: American Cancer Society Institution)

3. Goss PE, Lee BL, and Badovinac-Crnjevic T, et al (2013) Planning cancer control in Latin America and the Caribbean Lancet Oncol 14(5) 391-436 https://doi.org/10.1016/S1470-2045(13)70048-2 PMID: 23628188

4. Dolgin E (2018) Bringing down the cost of cancer treatment. Nature 555(7695) S26-S29 https://doi.org/10.1038/d41586-018-02483-3 PMID: 29517030

5. World Bank (2018) GDP per capita (current US\$) [https://www.worldbank.org/] Date accessed: 10/04/20

6. World Bank (2018) Classifying countries by income [https://datatopics.worldbank.org/world-development-indicators/stories/theclassification-of-countries-by-income.html]

7. Choi E, Lee S, and Nhung BC, et al (2017) Cancer mortality-to-incidence ratio as an indicator of cancer management outcomes in organization for economic cooperation and development countries Epidemiol Health 39 1-11 https://doi.org/10.4178/epih.e2017006

8. Parkin DM and Bray F (2008) Evaluation of data quality in the cancer registry: principles and methods Part II. Completeness Eur J Cancer 45(5) 756-764 https://doi.org/10.1016/j.ejca.2008.11.033

9. Vostakolaei FA, Karim-kos HE, and Janssen-heijnen MLG, et al (2010) The validity of the mortality to incidence ratio as a proxy for sitespecific cancer survival Eur J Public Health 21(5) 573-577 https://doi.org/10.1093/eurpub/ckq120

10. Batouli A, Jahanshahi P, and Gross CP, et al (2014) The global cancer divide: relationships between national healthcare resources and cancer outcomes in high-income vs. middle- and low-income countries J Epidemiol Glob Health 4(2) 115-124 https://doi.org/10.1016/j. jegh.2013.10.004 PMID: 24857179 PMCID: 7366371 
11. World Health Organization [https://www.who.int/]

12. Ministério da Saúde (2018) Estimativa 2018 - Incidência de Câncer No Brasil (Rio de Janeiro: Ministério da Saúde)

13. Kale MS and Korenstein D (2018) Overdiagnosis in primary care: framing the problem and finding solutions BMJ $362 \mathrm{k} 2820 \mathrm{https} / / \mathrm{doi}$. org/10.1136/bmj.k2820 PMID: 30108054 PMCID: 6889862

14. Finke I, Behrens G, and Weisser L, et al (2018) Socioeconomic differences and lung cancer survival - systematic review and metaanalysis Front Oncol 8536 https://doi.org/10.3389/fonc.2018.00536

15. Hassanipour-Azgomi S, Mohammadian-Hafshejani A, and Ghoncheh M, et al (2016) Incidence and mortality of prostate cancer and their relationship with the human development index worldwide Prostate Int 4(3) 118-124 https://doi.org/10.1016/j.prnil.2016.07.001 PMID: 27689070 PMCID: 5031898

16. Bellanger M, Zeinomar N, and Tehranifar P, et al (2018) Are global breast cancer incidence and mortality patterns related to country-specific economic development and prevention strategies? J Glob Oncol 4(4) 1-16 https://doi.org/10.1200/jgo.17.00207 PMID: 30085889 PMCID: 6223528

17. Khazaei Z, Sohrabivafa M, and Mansori K, et al (2018) Incidence and mortality of cervix cancer and their relationship with the human development index in 185 countries in the world: an ecology study in 2018 Adv Hum Biol 9(3) 222-227 https://doi.org/10.4103/AlHB. $\underline{\text { AlHB }}$

18. Ministério da Saúde (2015) Secretaria de Atenção à Saúde Diretrizes Para a Detecção Precoce Do Câncer de Mama No Brasil (Rio de Janeiro: Ministério da Saúde)

19. Rosa D, Barrios C, and Bines J, et al (2019) Abstract P1-08-29: current status of clinical and pathological characteristics of breast cancer patients in Brazil: results of the AMAZONA III study (GBECAM 0115) San Antonio Breast Cancer Symp 79(4)

20. Jedy-agba E, Mccormack $V$ and Adebamowo C (2016) Stage at diagnosis of breast cancer in sub-Saharan Africa: a systematic review and meta-analysis Lancet Glob Health 4(12) e923-e935 https://doi.org/10.1016/S2214-109X(16)30259-5 PMID: 27855871 PMCID: $\underline{5708541}$

21. Barrios CH, Reinert T and Werutsky G (2019) Access to high-cost drugs for advanced breast cancer in Latin America, particularly trastuzumab Ecancermedicalscience 13898 https://doi.org/10.3332/ecancer.2019.898 PMID: 30792815 PMCID: 6372298

22. Ades F, Senterre C, and Zardavas D, et al (2017) Are life-saving anticancer drugs reaching all patients ? Patterns and discrepancies of trastuzumab use in the European Union and the USA PLoS One 12(3) e0172351 https://doi.org/10.1371/journal.pone.0172351 PMCID: 5349665

23. Arnold M, Sierra MS, and Laversanne M, et al (2017) Global patterns and trends in colorectal cancer incidence and mortality Gut 66(4) 683-691 https://doi.org/10.1136/gutjnl-2015-310912 


\section{Appendix}

The classification defined by the World Bank for 2018 of Low, Lower-middle, Upper-middle and High-income has the following thresholds [5]:

\begin{tabular}{|l|c|}
\hline \multicolumn{1}{|c|}{ Threshold } & $\begin{array}{c}\text { Gross national income/ } \\
\text { capita (current US\$) }\end{array}$ \\
\hline Low-income & $1,026-3,995$ \\
\hline Lower-middle income & $3,995-12,375$ \\
\hline Upper-middle income & $>12,375$ \\
\hline High-income & \\
\hline
\end{tabular}

We present in the Appendix the data used for each primary site (Tables 1a-5a). GDP data was extracted from the World Bank database. Cancer incidence and mortality was extracted from the International Agency for Research on Cancer (an agency of the WHO). Only countries with incidence and mortality with an uncertainty level lower than $15 \%$ were considered to give more confidence to the data.

We also present the equations generated by the OLS models for each cancer primary site (Table 6a).

Table 1a. Data for breast cancer.

\begin{tabular}{|l|c|c|c|}
\hline \multicolumn{1}{|c|}{ Country name } & GDPpc & Breast cancer incidence & Breast cancer mortality \\
\hline United Arab Emirates & $40,698.84934$ & 52.9 & 16.9 \\
\hline Argentina & $14,398.35877$ & 73 & 18 \\
\hline Australia & $53,793.53726$ & 94.5 & 12.3 \\
\hline Austria & $47,380.82964$ & 71.1 & 14.3 \\
\hline Azerbaijan & $4,135.138601$ & 32.7 & 14.6 \\
\hline Belgium & $43,467.4459$ & 113.2 & 16.3 \\
\hline Bulgaria & $8,228.01157$ & 59.1 & 16.4 \\
\hline Bosnia and Herzegovina & $5,148.208517$ & 45.4 & 14.6 \\
\hline Belarus & $5,733.30721$ & 50.4 & 12.9 \\
\hline Brazil & $9,812.278531$ & 62.9 & 13 \\
\hline Bhutan & $3,130.233543$ & 5 & 12.7 \\
\hline Canada & $44,870.77616$ & 83.8 & 12.3 \\
\hline Switzerland & $80,342.84634$ & 88.1 & 11.1 \\
\hline Chile & $15,346.4497$ & 40.9 & 8.8 \\
\hline China & $8,826.994096$ & 36.1 & 11.9 \\
\hline Colombia & $6,408.920012$ & 44.1 & 12.2 \\
\hline Costa Rica & $11,677.26904$ & 46.7 & 14.5 \\
\hline Cuba & $8,433.092699$ & 44.2 & 85.7 \\
\hline Germany & $44,665.50637$ & 87.8 & \\
\hline Denmark & $57,218.85196$ & & \\
\hline
\end{tabular}


Table 1a. Continued.

\begin{tabular}{|c|c|c|c|}
\hline Algeria & $4,055.247211$ & 55.6 & 16.2 \\
\hline Ecuador & $6,273.488892$ & 31.8 & 9.1 \\
\hline Egypt, Arab Rep. & $2,412.727082$ & 52.4 & 21.3 \\
\hline Spain & $28,208.30041$ & 75.4 & 10.6 \\
\hline Ethiopia & 767.5634778 & 41.2 & 22.9 \\
\hline Finland & $45,804.65421$ & 89.5 & 11.3 \\
\hline France & $38,484.18992$ & 99.1 & 15.4 \\
\hline United Kingdom & $39,953.57306$ & 93.6 & 14.4 \\
\hline Ghana & $2,046.109986$ & 43 & 17.7 \\
\hline Greece & $18,885.47598$ & 69.3 & 13.5 \\
\hline Croatia & $13,386.51286$ & 68.7 & 18.2 \\
\hline Hungary & $14,278.8745$ & 85.5 & 17.9 \\
\hline Indonesia & $3,846.415709$ & 42.1 & 17 \\
\hline India & $1,979.364301$ & 24.7 & 13.4 \\
\hline Ireland & $68,885.45038$ & 90.3 & 17.6 \\
\hline Iran, Islamic Rep. & $5,593.853783$ & 31 & 8.7 \\
\hline Iraq & $5,017.968065$ & 38.4 & 13.6 \\
\hline Italy & $32,110.02726$ & 92.8 & 13.8 \\
\hline Japan & $38,430.29124$ & 57.6 & 9.3 \\
\hline Kazakhstan & $9,030.318806$ & 37.2 & 14.8 \\
\hline Kenya & $1,594.834926$ & 40.3 & 17.8 \\
\hline Lebanon & $8,808.589448$ & 97.6 & 25.3 \\
\hline Sri Lanka & $4,073.736519$ & 22.2 & 8.1 \\
\hline Lithuania & $16,809.64826$ & 59.6 & 16 \\
\hline Latvia & $15,684.55852$ & 62.8 & 17.7 \\
\hline Morocco & $3,022.92792$ & 51 & 17.6 \\
\hline Maldives & $11,151.06921$ & 41.2 & 16.6 \\
\hline Mexico & $8,910.333177$ & 39.5 & 9.9 \\
\hline Malaysia & $9,951.544153$ & 47.5 & 18.4 \\
\hline Nigeria & $1,968.425523$ & 41.7 & 18.8 \\
\hline Netherlands & $48,482.76621$ & 105.9 & 16.5 \\
\hline Norway & $75,704.2487$ & 87.5 & 11 \\
\hline New Zealand & $42,583.08473$ & 92.6 & 14.2 \\
\hline Pakistan & $1,547.853414$ & 43.9 & 23.2 \\
\hline Peru & $6,571.928645$ & 40 & 10.3 \\
\hline Philippines & $2,988.952703$ & 52.4 & 17.5 \\
\hline Poland & $13,863.54842$ & 59.1 & 15.8 \\
\hline
\end{tabular}


Table 1a. Continued.

\begin{tabular}{|l|c|c|c|}
\hline Portugal & $21,291.43121$ & 70.7 & 11.3 \\
\hline Qatar & $63,249.42243$ & 42.1 & 13.9 \\
\hline Romania & $10,819.24402$ & 51.6 & 14.6 \\
\hline Russian Federation & $10,749.05607$ & 53.6 & 15.1 \\
\hline Singapore & $57,714.29663$ & 64 & 18.5 \\
\hline Sierra Leone & 499.5291033 & 43.6 & 25.4 \\
\hline Serbia & $5,901.223013$ & 75.3 & 13.9 \\
\hline Slovenia & $23,601.40278$ & 68.5 & 11.4 \\
\hline Sweden & $53,253.47664$ & 89.8 & 14.4 \\
\hline Togo & 610.1517301 & 29 & 10.9 \\
\hline Thailand & $6,595.004125$ & 35.7 & 10.3 \\
\hline Tunisia & $3,464.41689$ & 32.2 & 16.7 \\
\hline Ukraine & $2,639.824326$ & 44.6 & 20.7 \\
\hline Uruguay & $16,245.59837$ & 65.2 & 12.7 \\
\hline United States & $59,927.93029$ & 84.9 & 11.8 \\
\hline Uzbekistan & $1,533.852038$ & 22.6 & 12.7 \\
\hline Yemen, Rep. & $1,106.803906$ & 24.9 & 16.3 \\
\hline South Africa & $6,151.077955$ & 49 & \\
\hline
\end{tabular}

Table 2a. Data for lung cancer.

\begin{tabular}{|l|c|c|c|}
\hline \multicolumn{1}{|c|}{ Country name } & GDPpc & Lung cancer incidence & Lung cancer mortality \\
\hline Albania & $4,537.579056$ & 22 & 19 \\
\hline Argentina & $14,398.35877$ & 18.9 & 17.1 \\
\hline Armenia & 3936.79832 & 29.2 & 27.2 \\
\hline Australia & $53,793.53726$ & 26.2 & 16.8 \\
\hline Austria & $47,380.82964$ & 27.8 & 21.8 \\
\hline Azerbaijan & $4,135.138601$ & 12.8 & 12 \\
\hline Belgium & $43,467.4459$ & 39 & 27.1 \\
\hline Bulgaria & $8,228.01157$ & 28.8 & 25.7 \\
\hline Bosnia and Herzegovina & $5,148.208517$ & 36.1 & 30.5 \\
\hline Belarus & $5,733.30721$ & 25.3 & 17.2 \\
\hline Bolivia & $3,393.955818$ & 7.7 & 7.2 \\
\hline Brazil & $9,812.278531$ & 13 & 12 \\
\hline Bhutan & $3,130.233543$ & 7.9 & 7.3 \\
\hline Canada & $44,870.77616$ & 30 & 23.5 \\
\hline Switzerland & $80,342.84634$ & 22.6 & 17.2 \\
\hline
\end{tabular}


Table 2a. Continued.

\begin{tabular}{|c|c|c|c|}
\hline Chile & $15,346.4497$ & 13.4 & 12.3 \\
\hline China & $8,826.994096$ & 35.1 & 30.9 \\
\hline Colombia & $6,408.920012$ & 10.1 & 9 \\
\hline Costa Rica & $11,677.26904$ & 6.6 & 5.5 \\
\hline Cuba & $8,433.092699$ & 31.1 & 25.8 \\
\hline Germany & $44,665.50637$ & 33.7 & 23.8 \\
\hline Denmark & $57,218.85196$ & 36.6 & 27.6 \\
\hline Dominican Republic & $7,052.258839$ & 12.4 & 11 \\
\hline Algeria & $4,055.247211$ & 10.1 & 10 \\
\hline Ecuador & $6,273.488892$ & 6.1 & 5.7 \\
\hline Egypt, Arab Rep. & $2,412.727082$ & 7.6 & 7.2 \\
\hline Spain & $28,208.30041$ & 27 & 21.2 \\
\hline Estonia & $20,200.37559$ & 29.6 & 23.7 \\
\hline Finland & $45,804.65421$ & 19.3 & 15.6 \\
\hline France & $38,484.18992$ & 36.1 & 26.3 \\
\hline United Kingdom & $39,953.57306$ & 32.5 & 22.2 \\
\hline Georgia & $4,045.418967$ & 17.3 & 16.1 \\
\hline Greece & $18,885.47598$ & 40.5 & 31.8 \\
\hline Guam & $35,675.79417$ & 37.9 & 35.7 \\
\hline Honduras & $2,480.125929$ & 5.7 & 5.2 \\
\hline Croatia & $13,386.51286$ & 32.5 & 30.5 \\
\hline Hungary & $14,278.8745$ & 56.7 & 44.4 \\
\hline Indonesia & $3,846.415709$ & 12.4 & 10.9 \\
\hline India & $1,979.364301$ & 5.4 & 5 \\
\hline Ireland & $68,885.45038$ & 33.7 & 22.1 \\
\hline Iran, Islamic Rep. & $5,593.853783$ & 9.1 & 8.3 \\
\hline Iraq & $5,017.968065$ & 10.7 & 10.4 \\
\hline Israel & $40,543.58417$ & 21.1 & 18.2 \\
\hline Italy & $32,110.02726$ & 24.4 & 19.2 \\
\hline Jordan & $4,129.751664$ & 18.4 & 16.8 \\
\hline Japan & $38,430.29124$ & 27.5 & 16.2 \\
\hline Kazakhstan & $9,030.318806$ & 21.6 & 19.4 \\
\hline Korea, Rep. & $29,742.83886$ & 27.8 & 18.1 \\
\hline Lebanon & 8,808.589448 & 23.2 & 21 \\
\hline Sri Lanka & $4,073.736519$ & 5.1 & 4.2 \\
\hline Lithuania & $16,809.64826$ & 26.6 & 21.7 \\
\hline Latvia & $15,684.55852$ & 25.9 & 21.2 \\
\hline
\end{tabular}


Table 2a. Continued.

\begin{tabular}{|c|c|c|c|}
\hline Morocco & $3,022.92792$ & 17.2 & 17 \\
\hline Maldives & $11,151.06921$ & 12.9 & 11.3 \\
\hline Mexico & $8,910.333177$ & 5.8 & 4.9 \\
\hline Mongolia & $3,717.473389$ & 19.6 & 17.4 \\
\hline Malaysia & $9,951.544153$ & 15.3 & 13.3 \\
\hline Netherlands & $48,482.76621$ & 33.3 & 26.5 \\
\hline Norway & $75,704.2487$ & 29.9 & 20.3 \\
\hline New Zealand & $42,583.08473$ & 25.3 & 18.1 \\
\hline Pakistan & $1,547.853414$ & 7.1 & 6.7 \\
\hline Peru & $6,571.928645$ & 9.1 & 8 \\
\hline Philippines & $2,988.952703$ & 21.2 & 19.2 \\
\hline Poland & $13,863.54842$ & 36.5 & 33.2 \\
\hline Portugal & $21,291.43121$ & 22.6 & 19 \\
\hline Romania & $10,819.24402$ & 29.8 & 26.3 \\
\hline Russian Federation & $10,749.05607$ & 24 & 21 \\
\hline Singapore & $57,714.29663$ & 28.6 & 26.1 \\
\hline El Salvador & $3,889.308769$ & 5.5 & 5.2 \\
\hline Serbia & $5,901.223013$ & 49.8 & 39.9 \\
\hline Slovenia & $23,601.40278$ & 32.9 & 27 \\
\hline Sweden & $53,253.47664$ & 17.4 & 14.9 \\
\hline Thailand & $6,595.004125$ & 20.4 & 18.7 \\
\hline Turkmenistan & $6,586.625863$ & 9.2 & 8.5 \\
\hline Tunisia & $3,464.41689$ & 13.9 & 13.3 \\
\hline Turkey & $10,546.15256$ & 36.9 & 35.9 \\
\hline Ukraine & $2,639.824326$ & 20.6 & 18.5 \\
\hline Uruguay & $16,245.59837$ & 27.8 & 24.8 \\
\hline United States & $59,927.93029$ & 35.1 & 22.1 \\
\hline Uzbekistan & $1,533.852038$ & 8.5 & 7.4 \\
\hline Vietnam & $2,342.244003$ & 21.7 & 19 \\
\hline South Africa & $6,151.077955$ & 17.3 & 16.4 \\
\hline
\end{tabular}

Table 3a. Data for colon cancer.

\begin{tabular}{|l|c|c|c|}
\hline \multicolumn{1}{|c|}{ Country name } & GDPpc & Colon cancer incidence & Colon cancer mortality \\
\hline United Arab Emirates & $40,698.84934$ & 12.6 & 6.3 \\
\hline Argentina & $14,398.35877$ & 19.6 & 10.7 \\
\hline Australia & $53,793.53726$ & 23.6 & 3.2 \\
\hline
\end{tabular}


Table 3a. Continued.

\begin{tabular}{|c|c|c|c|}
\hline Austria & $47,380.82964$ & 12.9 & 5.8 \\
\hline Azerbaijan & $4,135.138601$ & 4.9 & 3.4 \\
\hline Belgium & $43,467.4459$ & 23.1 & 7 \\
\hline Bulgaria & $8,228.01157$ & 16.3 & 11.1 \\
\hline Bosnia and Herzegovina & $5,148.208517$ & 11.8 & 6.1 \\
\hline Belarus & $5,733.30721$ & 19.2 & 8.8 \\
\hline Brazil & $9,812.278531$ & 10.6 & 5.6 \\
\hline Canada & $44,870.77616$ & 18.7 & 6.8 \\
\hline Switzerland & $80,342.84634$ & 14.2 & 5.3 \\
\hline Chile & $15,346.4497$ & 12.7 & 7.3 \\
\hline China & $8,826.994096$ & 12.9 & 6.3 \\
\hline Colombia & $6,408.920012$ & 9.8 & 5.7 \\
\hline Costa Rica & $11,677.26904$ & 10.5 & 6.3 \\
\hline Cuba & $8,433.092699$ & 13 & 9.1 \\
\hline Germany & $44,665.50637$ & 15.7 & 6.3 \\
\hline Denmark & $57,218.85196$ & 25.2 & 8.9 \\
\hline Algeria & $4,055.247211$ & 8.1 & 4.3 \\
\hline Ecuador & $6,273.488892$ & 7.1 & 4.4 \\
\hline Egypt, Arab Rep. & $2,412.727082$ & 4.2 & 2.5 \\
\hline Spain & $28,208.30041$ & 21 & 8.7 \\
\hline Finland & $45,804.65421$ & 15.4 & 5.4 \\
\hline France & $38,484.18992$ & 18.5 & 7.2 \\
\hline United Kingdom & $39,953.57306$ & 20.2 & 5.9 \\
\hline Greece & $18,885.47598$ & 20.8 & 8.3 \\
\hline Croatia & $13,386.51286$ & 22 & 11.9 \\
\hline Hungary & $14,278.8745$ & 32.6 & 13.6 \\
\hline Indonesia & $3,846.415709$ & 6.2 & 3.9 \\
\hline India & $1,979.364301$ & 2.2 & 1.5 \\
\hline Ireland & $68,885.45038$ & 21.4 & 5.2 \\
\hline Iran, Islamic Rep. & $5,593.853783$ & 8.6 & 4.9 \\
\hline Iraq & $5,017.968065$ & 4.2 & 2.4 \\
\hline Israel & $40,543.58417$ & 14 & 7.4 \\
\hline Italy & $32,110.02726$ & 20.6 & 7.6 \\
\hline Japan & $38,430.29124$ & 24.3 & 7.8 \\
\hline Kazakhstan & $9,030.318806$ & 8.1 & 5 \\
\hline Korea, Rep. & $29,742.83886$ & 24.7 & 5.1 \\
\hline
\end{tabular}


Table 3a. Continued.

\begin{tabular}{|c|c|c|c|}
\hline Lebanon & $8,808.589448$ & 15 & 8.2 \\
\hline Sri Lanka & $4,073.736519$ & 2 & 1.1 \\
\hline Lithuania & $16,809.64826$ & 15.9 & 7.1 \\
\hline Latvia & $15,684.55852$ & 17.5 & 6.9 \\
\hline Moldova & $2,290.23515$ & 17.6 & 9.4 \\
\hline Maldives & $11,151.06921$ & 6.5 & 3.7 \\
\hline Mexico & $8,910.333177$ & 7.9 & 4.2 \\
\hline Malaysia & $9,951.544153$ & 11.4 & 6.9 \\
\hline Netherlands & $48,482.76621$ & 25.3 & 9.9 \\
\hline Norway & $75,704.2487$ & 27.8 & 9.4 \\
\hline New Zealand & $42,583.08473$ & 22.3 & 7.6 \\
\hline Peru & $6,571.928645$ & 8.8 & 5.2 \\
\hline Philippines & $2,988.952703$ & 12.4 & 7.6 \\
\hline Poland & $13,863.54842$ & 15.9 & 9.8 \\
\hline Portugal & $21,291.43121$ & 21.7 & 9.6 \\
\hline Romania & $10,819.24402$ & 14.5 & 8.3 \\
\hline Russian Federation & $10,749.05607$ & 15.3 & 8.4 \\
\hline Singapore & $57,714.29663$ & 23.6 & 10.7 \\
\hline Serbia & $5,901.223013$ & 17.7 & 9.2 \\
\hline Slovenia & $23,601.40278$ & 26 & 7.4 \\
\hline Sweden & $53,253.47664$ & 17.1 & 6.8 \\
\hline Thailand & $6,595.004125$ & 8 & 4.5 \\
\hline Tunisia & $3,464.41689$ & 6.8 & 3.8 \\
\hline Turkey & $10,546.15256$ & 11.8 & 8.1 \\
\hline Ukraine & $2,639.824326$ & 14 & 7.9 \\
\hline Uruguay & $16,245.59837$ & 24.6 & 11.8 \\
\hline United States & $59,927.93029$ & 15.9 & 6.3 \\
\hline Vietnam & $2,342.244003$ & 5 & 2.8 \\
\hline South Africa & 6,151.077955 & 9.1 & 5.3 \\
\hline
\end{tabular}

Table 4a. Data for prostate cancer.

\begin{tabular}{|l|c|c|c|}
\hline \multicolumn{1}{|c|}{ Country name } & GDPpc & Prostate cancer incidence & Prostate cancer mortality \\
\hline Argentina & $14,398.35877$ & 42.4 & 12.3 \\
\hline Australia & $53,793.53726$ & 85.6 & 10 \\
\hline Austria & $47,380.82964$ & 61.6 & 9.5 \\
\hline Belgium & $43,467.4459$ & 65.5 & 8.7 \\
\hline
\end{tabular}


Table 4a. Continued.

\begin{tabular}{|c|c|c|c|}
\hline Bulgaria & $8,228.01157$ & 53.6 & 12.5 \\
\hline Bosnia and Herzegovina & $5,148.208517$ & 26.3 & 11.5 \\
\hline Belarus & $5,733.30721$ & 49.4 & 13.6 \\
\hline Bolivia & $3,393.955818$ & 34.2 & 9.1 \\
\hline Brazil & $9,812.278531$ & 74 & 13.6 \\
\hline Canada & $44,870.77616$ & 58.2 & 7.8 \\
\hline Switzerland & $80,342.84634$ & 77.4 & 11.1 \\
\hline Chile & $15,346.4497$ & 51.2 & 15.8 \\
\hline China & $8,826.994096$ & 9.1 & 4.7 \\
\hline Colombia & $6,408.920012$ & 49.8 & 12 \\
\hline Cuba & $8,433.092699$ & 48.6 & 22.3 \\
\hline Germany & $44,665.50637$ & 63.2 & 11.3 \\
\hline Denmark & $57,218.85196$ & 75.9 & 15.8 \\
\hline Dominican Republic & $7,052.258839$ & 60.1 & 28 \\
\hline Algeria & $4,055.247211$ & 13 & 4.5 \\
\hline Ecuador & $6,273.488892$ & 38.8 & 13.9 \\
\hline Spain & $28,208.30041$ & 73.1 & 7.4 \\
\hline Finland & $45,804.65421$ & 71.6 & 10.8 \\
\hline France & $38,484.18992$ & 99 & 8.1 \\
\hline United Kingdom & $39,953.57306$ & 80.7 & 12.7 \\
\hline Greece & $18,885.47598$ & 50.5 & 8.8 \\
\hline Guatemala & $4,470.989572$ & 39.9 & 13.2 \\
\hline Croatia & $13,386.51286$ & 54.5 & 15.5 \\
\hline Hungary & $14,278.8745$ & 60.2 & 11.8 \\
\hline India & $1,979.364301$ & 4.4 & 2.9 \\
\hline Ireland & $68,885.45038$ & 132.5 & 11.4 \\
\hline Iran, Islamic Rep. & $5,593.853783$ & 16.6 & 8.3 \\
\hline Iraq & $5,017.968065$ & 6.6 & 2 \\
\hline Italy & $32,110.02726$ & 61.3 & 6 \\
\hline Japan & $38,430.29124$ & 35.4 & 4.4 \\
\hline Kazakhstan & $9,030.318806$ & 12.8 & 7 \\
\hline Korea, Rep. & $29,742.83886$ & 36.2 & 4.7 \\
\hline Lebanon & $8,808.589448$ & 39.3 & 11.9 \\
\hline Sri Lanka & $4,073.736519$ & 4 & 2.2 \\
\hline Lithuania & $16,809.64826$ & 70.2 & 18.1 \\
\hline Latvia & $15,684.55852$ & 80.3 & 21 \\
\hline Morocco & $3,022.92792$ & 22.7 & 10.9 \\
\hline
\end{tabular}


Table 4a. Continued.

\begin{tabular}{|c|c|c|c|}
\hline Maldives & $11,151.06921$ & 10.4 & 6.6 \\
\hline Mexico & $8,910.333177$ & 41.6 & 10 \\
\hline Malaysia & $9,951.544153$ & 12.4 & 5.6 \\
\hline Nigeria & $1,968.425523$ & 32.8 & 16.3 \\
\hline Netherlands & $48,482.76621$ & 68.9 & 11.7 \\
\hline Norway & $75,704.2487$ & 106.5 & 16.1 \\
\hline New Zealand & $42,583.08473$ & 90.8 & 11.6 \\
\hline Pakistan & $1,547.853414$ & 6.7 & 5 \\
\hline Panama & $15,196.39734$ & 60.7 & 15.4 \\
\hline Peru & $6,571.928645$ & 47.8 & 15.6 \\
\hline Philippines & $2,988.952703$ & 22.9 & 12.6 \\
\hline Poland & $13,863.54842$ & 43.7 & 14.5 \\
\hline Portugal & $21,291.43121$ & 59.5 & 10.6 \\
\hline Romania & $10,819.24402$ & 30.5 & 10.8 \\
\hline Russian Federation & $10,749.05607$ & 39.4 & 13.6 \\
\hline Singapore & $57,714.29663$ & 64.1 & 8.1 \\
\hline Sierra Leone & 499.5291033 & 29 & 20 \\
\hline Serbia & $5,901.223013$ & 35.4 & 13.1 \\
\hline Slovenia & $23,601.40278$ & 79.3 & 14.4 \\
\hline Sweden & $53,253.47664$ & 103 & 15 \\
\hline Togo & 610.1517301 & 20.4 & 13.1 \\
\hline Tunisia & $3,464.41689$ & 12.3 & 5.7 \\
\hline Ukraine & $2,639.824326$ & 32 & 13.8 \\
\hline Uruguay & $16,245.59837$ & 59.6 & 17.1 \\
\hline United States & $59,927.93029$ & 75.7 & 7.7 \\
\hline South Africa & 6,151.077955 & 68 & 27.9 \\
\hline
\end{tabular}

Table 5a. Data for cervical cancer.

\begin{tabular}{|l|c|c|c|}
\hline \multicolumn{1}{|c|}{ Country name } & GDPpc & Cervical incidence & Cervical mortality \\
\hline Argentina & $14,398.35877$ & 16.7 & 7.7 \\
\hline Australia & $53,793.53726$ & 6 & 1.7 \\
\hline Azerbaijan & $4,135.138601$ & 6.5 & 4.6 \\
\hline Bolivia & $3,393.955818$ & 38.5 & 19 \\
\hline Brazil & $9,812.278531$ & 12.2 & 5.8 \\
\hline Bhutan & $3,130.233543$ & 14.4 & 10.2 \\
\hline Canada & $44,870.77616$ & 5.7 & 1.7 \\
\hline
\end{tabular}


Table 5a. Continued.

\begin{tabular}{|c|c|c|c|}
\hline Chile & $15,346.4497$ & 12.2 & 5 \\
\hline China & $8,826.994096$ & 10.7 & 4.4 \\
\hline Colombia & $6,408.920012$ & 12.7 & 5.7 \\
\hline Cuba & $8,433.092699$ & 14.6 & 6 \\
\hline Germany & $44,665.50637$ & 7.5 & 2.2 \\
\hline Algeria & $4,055.247211$ & 8.1 & 5.5 \\
\hline Ecuador & $6,273.488892$ & 17.8 & 9 \\
\hline Spain & $28,208.30041$ & 5.2 & 1.7 \\
\hline France & $38,484.18992$ & 6.7 & 2.3 \\
\hline United Kingdom & $39,953.57306$ & 8.4 & 1.7 \\
\hline Ghana & $2,046.109986$ & 32.9 & 23 \\
\hline Guatemala & $4,470.989572$ & 21.1 & 11.7 \\
\hline Honduras & $2,480.125929$ & 19.6 & 12.5 \\
\hline Hungary & $14,278.8745$ & 17.2 & 5.1 \\
\hline Indonesia & $3,846.415709$ & 23.4 & 13.9 \\
\hline India & $1,979.364301$ & 14.7 & 9.2 \\
\hline Iran, Islamic Rep. & $5,593.853783$ & 2.2 & 1.2 \\
\hline Italy & $32,110.02726$ & 7.1 & 1.5 \\
\hline Japan & $38,430.29124$ & 14.7 & 2.7 \\
\hline Kazakhstan & $9,030.318806$ & 15.7 & 7.5 \\
\hline Kenya & $1,594.834926$ & 33.8 & 22.8 \\
\hline Korea, Rep. & $29,742.83886$ & 8.4 & 2 \\
\hline Sri Lanka & $4,073.736519$ & 7.8 & 4.2 \\
\hline Morocco & $3,022.92792$ & 17.2 & 12.6 \\
\hline Maldives & $11,151.06921$ & 23.2 & 13.4 \\
\hline Mexico & $8,910.333177$ & 11 & 5.8 \\
\hline Mali & 827.0064008 & 43.9 & 36.2 \\
\hline Mozambique & 426.2219619 & 42.8 & 35.7 \\
\hline Malaysia & $9,951.544153$ & 10.5 & 6 \\
\hline Nigeria & $1,968.425523$ & 27.2 & 20 \\
\hline Peru & $6,571.928645$ & 23.2 & 10.2 \\
\hline Philippines & $2,988.952703$ & 14.9 & 8.8 \\
\hline Poland & $13,863.54842$ & 9.4 & 4.9 \\
\hline Romania & $10,819.24402$ & 19.5 & 8.9 \\
\hline Russian Federation & $10,749.05607$ & 17 & 6.2 \\
\hline Sierra Leone & 499.5291033 & 13.8 & 12 \\
\hline El Salvador & $3,889.308769$ & 18.5 & 9.4 \\
\hline
\end{tabular}


Table 5a. Continued.

\begin{tabular}{|l|c|c|c|}
\hline Serbia & $5,901.223013$ & 20.3 & 7 \\
\hline Togo & 610.1517301 & 23.8 & 18.7 \\
\hline Thailand & $6,595.004125$ & 16.2 & 9 \\
\hline Turkey & $10,546.15256$ & 4.8 & 2.5 \\
\hline Uganda & 606.4684535 & 54.8 & 40.5 \\
\hline Ukraine & $2,639.824326$ & 17 & 6.6 \\
\hline United States & $59,927.93029$ & 6.5 & 1.9 \\
\hline Uzbekistan & $1,533.852038$ & 9.9 & 5.4 \\
\hline Vietnam & $2,342.244003$ & 7.1 & 4 \\
\hline South Africa & $6,151.077955$ & 43.5 & 19.2 \\
\hline Zimbabwe & $1,333.395663$ & 62.3 & 46 \\
\hline
\end{tabular}

Table 6a. Equations generated by the regression of each primary site. For all of them, the GDPpc coefficients were negative and statistically significant, indicating a negative correlation between income and lethality of cancer.

\begin{tabular}{|l|l|}
\hline Breast & MIR $=1.05-0.082 . \operatorname{In}$ (GDPpc) \\
\hline Lung & MIR $=1.41-0.060 . \ln$ (GDPpc) \\
\hline Colon & MIR $=1.36-0.091 . \ln$ (GDPpc) \\
\hline Prostate & MIR $=1.46-0.123 . \ln$ (GDPpc) \\
\hline Cervix & MIR $=1.58-0.122 . \ln$ (GDPpc) \\
\hline
\end{tabular}

